\title{
Mengapa Go-Jek? \\ Studi mengenai motivasi pengemudi Go-Jek di Salatiga
}

\author{
Anggit Wahyu Saputra \\ Fakultas Ekonomika dan Bisnis, Universitas Kristen Satya Wacana \\ 222015026@student.uksw.edu \\ Henry Wijaya Budiono \\ Fakultas Ekonomika dan Bisnis, Universitas Kristen Satya Wacana \\ Prapto Yuwono \\ Fakultas Ekonomika dan Bisnis, Universitas Kristen Satya Wacana
}

\begin{abstract}
This research aims to find out what is the motivation of driver's Go-Jek. This research uses phenomenological method. Go-Jek is an online application that helps customers to get transportation mode easily. Recently, Go-Jek has been providing a job opportunity for people, as it operates widely in cities in Indonesia. There are some people who joined Go-Jek for some reasons, and this study seeks to find the motivation of some people in joining Go-Jek. Our study reveals that the drivers join Go-Jek as their main job and some others being drivers as their side job. We found that those who work as Go-Jek driver for side job is usually in their process to find another jobs, and Go-Jek provides opportunity for them to have activities while they are unemployed.
\end{abstract}

Keywords: Go-Jek, Online Application, Motivation, Phenomenological theory

\begin{abstract}
ABSTRAK
Penelitian ini adalah untuk mengetahui apa motivasi pengemudi go-jek. Penelitian ini menggunakan metode fenomena kehendak. Go-jek merupakan aplikasi online yang membantu pelanggan supaya untuk mendapatkan mode transportasi dengan mudah dan cepat. Selama ini, Go-jek telah menyediakan kesempatan kerja bagi orang-orang, karena ia beroperasi secara luas di kota-kota di Indonesia. Ada beberapa orang yang bergabung menjadi pengemudi Go-Jek dengan beberapa alasan, dan studi ini dilakukan untuk menemukan motivasi orang-orang menjadi pengemudi Go-Jek. Studi kami menemukan bahwa pengemudi Go-Jek menjadikan Go-Jek sebagai pekerjaan utama dan pekerjaan sampingan. Kami juga menemukan bahwa mereka yang menjadi pengemudi Go-Jek untuk pekerjaan sampingan sedang dalam proses mencari pekerjaan lain dan Go-Jek memberikan kesempatan bagi mereka untuk beraktivitas selama masa "menganggur".
\end{abstract}

Kata Kunci: Go-Jek, aplikasi online, motivasi, teori fenomenologi 
Dinamika Sosial Budaya, Vol 21, No. 1, Juni 2019, pp 13-18

p-ISSN: 1410-9859\& e-ISSN: 2580-8524

http://journals.usm.ac.id/index.php/jdsb

\section{Pendahuluan}

Go-jek digagas pertama kali pada tahun 2010 dengan sistem telepon, kemudian sempat vakum dalam jangka waktu lama dan muncul kembali dengan model baru berbasis aplikasi pada tahun 2015. Go-jek bermitra dengan sekitar 200.000 pengendara go-jek yang berpengalaman dan terpercaya di Indonesia, untuk menyediakan berbagai macam layanan,termasuk pesan transportasi dan pesan antar makanan. Kegiatan go-jek bertumpu pada tiga nilai pokok: kecepatan, inovasi dan dampak sosial. Go-jek telah resmi beroperasi di 10 kota besar di Indonesia, termasuk Jakarta, Bandung, Bali, Surabaya, Makasar, Yogyakarta, Medan, Semarang, Palembang dan Balikpapan.(Hendrastomo dkk,2016).

Go-jek merupakan sebuah fenomena yang memobilisasi tenaga kerja yang mendorong penciptaan lapangan tenaga kerja dengan menarik minat banyak orang baik yang masih mempunyai pekerjaan maupun yang belum untuk bergabung di go-jek (Hendrastomo dkk,2016). Kebanyakan orang mau masuk ke dunia go-jek dikarenakan manfaat yang diperoleh cukup menggiurkan yaitu dapat meningkatkan kualitas hidupnya. Uni sesuai dengan penelitian yang dilakukan oleh Rakhmani, Inaya dkk, (2018). bahwa 90\% mitra pengemudi merasa kualitas hidupnya lebih baik-jauh lebih baik setelah bergabung dengan Go-Jek.
Wisana, I ddk. Dalam temuanya mengungkapkan bahwa mitra pengemudi merasa puas (74\%) dan sangat puas (23\%) dengan fleksibilitas yang didapatkan. Mitra pengemudi merasa diuntungkan (47\%) dan sangat diuntungkan (5\%) oleh hubungan kemitraan dengan Go-jek. Dalam penelitian Wisana, I. dkk menunjukan bahwa keuntungan yang didapat dari go-jek cukup lumayan, sehingga banyak sekali minat dari orang-orang untuk masuk ke Go-jek.

Minat masyarakat untuk menjadi pengemudi gojek menunjukkan bahwa mereka tidak mempersoalkan pekerjaan yang bersifat formal untuk memenuhi kebutuhan hidupnya, apalagi mereka yang menjadi pengemudi gojek sebagai pekerjaan utamanya. Oleh sebab itu pertanyaan penelitian ini adalah "Mengapa seseorang berminat menjadi pengemudi GoJek?" Penelitian ini bertujuan untuk menggali motivasi pengemudi Go-Jek terkait dengan minat mereka bergabung dengan Go-Jek. Hasil studi akan bermanfaat untuk secara teoritis memberikan kontribusi tentang motivasi seseorang untuk menjadi pengemudi Go-Jek.

\section{Metode Penelitian}

Penelitian ini merupakan penelitian kualitatif dengan menggunakan metode penelitian phenomenology oleh (Paul Recould), Langkahlangkah metode: pertama perumusan masalah penelitian, kedua pra study atau penelitian pendahuluan,ketiga pemilihan skema referensi keempat mempelajari sudut pandang masalah 
Dinamika Sosial Budaya, Vol 21, No. 1, Juni 2019, pp 13-18

p-ISSN: 1410-9859\& e-ISSN: 2580-8524

http://journals.usm.ac.id/index.php/jdsb

yang akan distudi, kelima membangun model teori keenam memeriksa dampak yang tidak diinginkan, ketujuh menghubungkan hasil penelitian dengan literature (pustaka)

a. Deskripsi penelitian

Penelitian ini dilakukan di Salatiga, Jawa

Tengah. Sebagai responden, kami mencari delapan orang pengemudi Go-Jek di Salatiga. Penentuan responden dilakukan secara accidental sampling, yaitu menjadikan pengemudi Go-Jek yang ditemui saat itu sebagai responden. Teknik pengambilan sampel dilakukan dengan melakukan wawancara mendalam terhadap kedelapan responden. Wawancara dilakukan selama kurang lebih 40 menit lalu hasilnya didokumentasikan dalam bentuk rekaman wawancara. Rekaman wawancara disusun menjadi transkrip rekaman wawancara untuk selanjutnya dilakukan pemadatan fakta dan diabstraksi. Hasil dijelaskan dalam bentuk narasi, dan nama responden dalam penelitian ini kami samarkan dengan nama lain.

b. Dengan adanya analisis data melalui metode diatas, kemudian kami dapat membuat kesimpulan berdasarkan hasil data yang telah kami peroleh.

\section{Hasil dan Pembahasan}

Salatiga merupakan kota kecil yang menjadi salah satu tempat bagi go-jek untuk menjalankan operasinya. Go-jek di salatiga beroperasi sejak tanggal 10 Mei 2017 lalu, akan tetapi, pelaksanaan operasional tersebut bukan tanpa kendala, pasalnya banyak pihak yang tidak senang kepada go-jek. Hal ini sampai memunculkan polemik yang berkepanjangan antara go-jek dan pihak-pihak yang merasa dirugikan atas hadirnya go-jek. Mereka menganggap go-jek mengambil pendapatan harian mereka. Kendati demikian go-jek tetap beroperasi sampi hari ini. Jumlah pengemudi gojek di Salatiga saat ini sekitar.

\section{Motivasi pengemudi go-jek sebagai pekerjaan pokok}

Para driver go-jek menjadikan pekerjaan go-jek sebagai penghasilan utama. Alasan mengapa mereka menjadikan go-jek sebagai penghasilan utama juga bervariasi, seperti menurut driver yang bernama Yudi(23) seorang driver go-jek dari Salatiga. Ia mengungkapkan bahwa upah gojek yang tinggi, membuatnya rela untuk meninggalkan pekerjaan lamanya..

'pekerjaan saya sebelumnya saya lepaskan.

Pekerjaan saya dulu, merakit anyaman atau sejenis parsel. Kalau parsel itu pengasilanya cukup ya, kan borongan, jadi kalau ada barang pendapatan saya waktu itukan 1 bln antara ya boleh dikatakan 2-3 jt, tapi kalau go-jek, intinya selagi kita mau keluar, waktu ada, tergantung nasib kita juga, biasanya sih dalam 1 hari kalau kita bisa dapat rata-rata 100 ribu, belum insentif, bisa lebih, artinya kali 3 kan udah 3 jt belum masuk insentif, jadi saya menjadikan go-jek sebagai penghasillan utama saya".

(Yudi, 2018, 7 Juli) 
Dinamika Sosial Budaya, Vol 21, No. 1, Juni 2019, pp 13-18

p-ISSN: 1410-9859\& e-ISSN: 2580-8524

http://journals.usm.ac.id/index.php/jdsb

Kondisi yang sama juga diungkapkan oleh driver lainya. Seperti yang diungkapkan oleh Yatno(34) seorang driver dari blotongan, Salatiga. Ia rela meninggalkan pekerjaan sebelumnya demi pindah ke ojek online(go-jek). Ia mengungkapkan bahwa profesi go-jek dapat menambah penghasilanya

'saya sebelumnya, kerja di koperasi mas, serapi dana, di tingkir, cebongan, karena gojek lumayan juga saya alih profesi mas. Kebetulan dulu ada tawaran itu, dan coba masuk tawaran itu, eh ternyata ya lumayan juga sih mas buat harian(kebutuhan), kemudian masuk ke go-jek'”.

(Yatno, 2018, 7 Juli)

Selain itu pendapat lain juga diungkapkan oleh Anton(23) asal Sumogawe, Salatiga. Ia mengungkapakan termotivasi masuk ke go-jek karena selain bisa mendapatkan penghasilan juga bisa membuatnya bisa menabung, ungkap Anton.

'itu saya sebentar, sudah keluar dari pabrik mas, kan udaranya itu kan panas mas, tembus,. Harus pake kaca mata, bahaya sih sebenarnya,sangat beresiko banget. Aku baru 3 bulan lah di go-jek, iya 3 bulan, dampak positif dari go-jek, yaitu bisa punya tabungan yang banyak walaupun gak kerja dipabrik, kan bisa ngasih uang ke adik saya, orang tua saya, buat makan saya, ya buat kehidupan sehariharilah".

(Anton, 2018, 30 Juni)

Menurut Wahyudi(43) seorang driver asal getasan, ia berpendapat bahwa waktu luang,fleksibilitas dan menambah teman, merupakan motivasi mengapa ia masuk ke pekerjaan go-jek ini.

'Dulu saya ndak punya pekerjaan mas, terus saya masuk ke go-jek, dan saya fokus di pekerjaan ini. ya yang jelas banyak waktu kosong mas, enaknya di jalan gini banyak temannyalah,. Bisa kumpul sama teman-teman gini, terus waktunya gak tertekan'.

Wahyudi, 2018, 30 Juni)

Dalam hasil wawancara tersebut, kami menemukan bahwa tingkat pendapatan yang diperoleh dari go-jek yang cenderung tinggi membuat mereka rela melepas pekerjaan mereka sebelumnya. Hal lain yaitu mereka juga bisa menambah sampingan dan juga bisa menabung dari keuntungan go-jek tersebut.

\section{Motivasi pengemudi go-jek sebagai pekerjaan sampingan}

Sedangkan para driver yang menjadikan go-jek sebagai pendapatan sampingan, mengungkapkan bahwa mereka masuk ke profesi go-jek karena profesi tersebut bisa menambah penghasilan atau dapat menambah pendapatan lain dan juga sebagai sarana mengisi waktu luang.

Menurut Heru(34) driver go-jek asal tingkir, mengungkapkan bahwa ia menjadikan go-jek sebagai penghasilan sampingan karena ia ingin mengisi waktu luang, ia mengungkapkan bahwa pendapatan sampingan dari go-jek bisa mengisi waktu luangnya dan ia juga sedang mencari pekerjaan lainya. Oleh karena itu, sambil bekerja sebagai go-jek ia juga melamar pekerjaan lain. 
Dinamika Sosial Budaya, Vol 21, No. 1, Juni 2019, pp 13-18

p-ISSN: 1410-9859\& e-ISSN: 2580-8524

http://journals.usm.ac.id/index.php/jdsb

" ya sebenarnya ini gak terlalu menarik

ya, karena ini cuma buat sampingan, buat

tambah-tambah uang sakulah, uang jajan.

Saya dulu di pabrik, tapi sudah keluar, ini

baru mau cari lagi tapi baru melamar-

lamar juga sih. Jadi itu intinya ini itu buat

mengisi waktu luang dari pada nganggur,

tapi ya ini masuk ke lamaran kemana-

mana, juga di PT, di Rumah Makan juga,

gitu',.

(Heru, 2018, 7 Juli)

Driver go-jek lain, mengungkapkan

bahwa alasanya masuk ke profesi go-jek adalah karena kebutuhanya. Seperti pendapat Yanto(23) dari blotongan.

' 'Ini cuma buat sampingan mas, gak fokus, atau cuma mengisi waktu luang saja.

Sekarang go-jek banyak ordernya jadi ya.. saya juga kerja dikoperasi mas,kalau sambil go-jek kan lumayan, bisa nambah penghasilan'”.

(Yanto,2018, 30 Juni)

Driver go-jek yang bernama Timan(34) getasan, juga menyatakan alasan mengapa masuk ke gojek adalah untuk menambah penghasilan sampingan. Dalam penghasilan tambahan tersebut dapat memenuhi kebutuhanya seharihari.

" saya puas mas, karena kebutuhanyakan bisa tambah. Jadi rejeki itu bisa nambah mas. Saya juga seorang buruh mas, buruh perantauan. Sebagai marmer slep'”.

(Timan, 2018, 7 Juli)
Dari wawancara kepada driver yang menjadikan go-jek sebagai penghasilan sampingan, kami dapat menyimpulkan bahwa mengapa mereka masuk ke profesi go-jek adalah karena adanya tujuan lain seperti mengisi waktu luang dan tambahan kebutuhan.

Dalam penelitian yang dilakukan oleh Hendrastomo (2016), menyatakan bahwa orang akan memilih rasional dalam tuntutan hasil, sebagaimana seperti seseorang terhadap pekerjaanya, sebagai driver go-jek, pertimbangan akan tuntutan hasil mengubah pemikiran seseorang terhadap tindakanya. Di dalam go-jek pendapatan yang cenderung tinggi membuat orang-orang mengubah mindsetnya untuk rela meninggalkan pekerjaanya demi masuk ke profesi go-jek yang notabenenya memiliki tingkat upah yang lebih tinggi.

Ini menunjukan kesamaan dalam hal pandangan,bagaimana para driver go-jek mengambil keputusan untuk masuk ke profesi go-jek. Pada umumnya para driver go-jek termotivasi dengan tingkat upah yang cenderung tinggi, oleh kerena itu mereka memutuskan untuk masuk ke pekerjaan go-jek. Menurut Kusuma (2016), ' bekerja dengan jadwal yang fleksibel membuat pekerja lebih bersemangat kerja, meskipun pemantauan tetap dijalankan berdasarkan target. Hal ini juga yang dilakukan di gojek dimana driver diberi kebebasan untuk menentukan kapan mereka akan melakukan pekerjaannya, tetapi manajemen Gojek telah menetapkan target perhari dimanaminimal setiap driver gojek mengumpulkan 14 poin". 
Dinamika Sosial Budaya, Vol 21, No. 1, Juni 2019, pp 13-18

p-ISSN: 1410-9859\& e-ISSN: 2580-8524

http://journals.usm.ac.id/index.php/jdsb

Fleksibilitas waktu ikut serta menjadi salah satu motivasi bagi para driver go-jek. Dengan manfaat dari fleksibilitas yang ada pada go-jek, memudahkan dan membuat para driver lebih santai, artinya para pengemudi go-jek dapat mengatur waktu mereka dalam melakukan pekerjaanya tanpa ada paksaan aturan. Hal ini, mengindikasikan kesamaan pandangan dengan peneliti lain bahwa, dengan adanya fleksibilitas membuat driver go-jek semakin termotivasi untuk menekuni profesi ojek online (go-jek) tersebut.

'Keuntungan menjadi driver GOJEK
adalah sifatnya yang fleksibel dan tidak
terbatas sesuai keinginan driver. Hal ini
menguntungkan bagi mereka yang
menjadikan GOJEK sebagai pekerjaan
sampingan."'(Junior, M.S. 2017.)

\section{Kesimpulan}

Dalam penelitian ini,
perbedaan motivasi antara go-jek sebagai
pekerjaan sampingan dan go-jek sebagai
pekerjaan utama. Motivasi pekerjaan go-jek
sebagai pekerjaan pokok, yaitu adanya
perbandingan upah yang cenderung tinggi
membuat mereka rela meninggalkan pekerjaan
lamanya dan menjadikan go-jek sebagai
pekerjaan utama. Ditambah lagi alasan waktu
yang fleksibel membuat para go-jek termotivasi
untuk menggeluti usaha ojek online tersebut.
Sedangkan motivasi pekerjaan go-jek sebagai
sampingan adalah karena mereka mempunyai
tujuan lain seperti mengisi waktu luang yang

tujuanya untuk melamar pekerjaan ,untuk menabung, dan juga karena waktu yang fleksibel membuat driver termotivasi untuk masuk ke pekerjaan go-jek tersebut.

\section{Daftar Pustaka}

Hendrastomo, G., N.E. Januarti, V.I.S. Pinasti, M.Aulia, A.T.Firman, T.T.Hidayat. (2016). Dilema Sosial Ojek Online. [Laporan Penelitian] Fakultas Ilmu Sosial. Universitas Negeri Yogyakarta. Yogyakarta.

Wisana, I.Dewa.G.K, Inaya R, A.Primaldhi, P.Walandouw, A.H.Nugroho. (2018). Dampak GO-JEK terhadap Perekonomian Indonesia. [Riset UI] Lembaga Demografi, Fakultas Ekonomika dan Bisnis. Universitas Indonesia. Jakarta.

Laiya, Bakhtiar, Y.Chrisna, T.Ningsih, S.Zania, R.A.N.Siregar, Manesa, E.Oktiaputri. (2017). Kreativitas gojek dalam persaingan transportasi.Jakarta : Fakultas Ilmu Kominikasi. Universitas Mercu Buana

Munir, syahrul. (2017). Go-Jek hentikan rekruitmen di Salatiga. Kompas. Salatiga

Rifaldi, Kadunci, Susilowati. (2016). Pengaruh Kualitas Pelayanan Transportasi Online Go-Jek Terhadap Kepuasan Pelanggan Pada Masa Mahasiswa/i Administrasi Niaga Politeknik Negeri Jakarta. Jakarta. Administrasi Bisnis Terapan, Politeknik Negeri Jakarta. Vol. 13 No. 2 Oktober 2016.

Junior, M.S. (2017). Fungsionalitas Konflik Gojek: Studi Fenomenologi Terhadap Konflik Pengemudi Gojek di Kota Kediri. Program Studi Magister Sosiologi. Universitas Sebelas Maret. 